\title{
§1。緒言
}

粉末の性質を支配するすのはいうまでるなく粒度分布 そ平均粒大（または比表面積）であって，これらを独立 K，しかる任意に希望の値に調整することは製品の品質 向上にとって非常に重要な事柄である。しかるに一定の 粉碎機を用いるとき，たとえば水平回転ミルのこときで は，粒度分布は一定の法則促従い，しかる比表面積は従 属的炕定まる。いかかれればこの両者はいずれか一方を 希望のるのにすれば他は自然にきまってしまうわけで， 粉碎条件たとえば粉碎媒体の量や大きさの配列を変更し て粒度分布を若干変えることができるとしてる，その方 法はきわめて不確実であり，が大幅倅化させること は忹とんど不可能と考えられる。

これに反して閉回路方式を用いれば，この点はかなり 満足されるのであって, 最近米・独などであ改めて注目 されつつあるよ5であるか，従来操作的には行われてき たとしても定量的な取扱いは全然といってよいるど考え られていないため，希望の製品を得るためには一体どの 上うな操作条件を選べばよいか，また輸送装固の設計を いかにすればよいか，などの工学的諸問題は全く不明の 状態沉る。筆者らは $2 ， 3$ の仮定に基ついて閉回路粉 碎方式の一般理論を導き, 粉末度, 循環比, セパレータ の分離限界径その他の諸変数の間の関保を，直ちに読み とれるチャートを作製し，から諸変数と循瑟比の関係を 追跡することによって, 合理的な設計や操作を行うのK 指針を与えた。

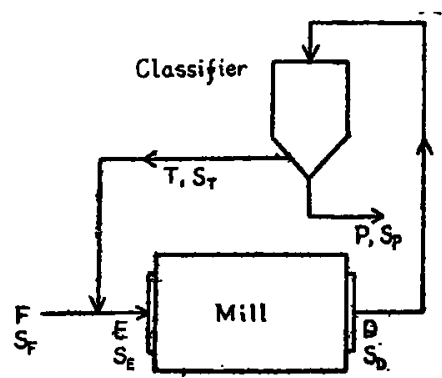

Fig. 1

Schematic diagram of general closed-circuit operation

* 昭和 31 年12月 24 日受理

* 全沢大学工学部
§2. 閉回路 粉砕における物 梊收支

Fig. 1は閉回 路方式のもっと る一般的な場 合を示す図であ る。すなわち粉 碚機, 選粉機特 よび輸送装置を
含み，乾式，湿式いずれをあ採用できる。ミルより出た 碚製物は一旦セパレータで節われ，一定の分離径より大 きい粗粒は再びミルへ戻され，他は製品となる。

い单位時間当りの処理量を $F$, 製品を $P$ ，ミルの确 製物を $D$ (セレクターへの供給量)，ミル送入量を $E$ お。 よび循環量（Recycle）をTで表わし，各粉末の比表面 糟 $S$ をれぞれ上と同じ添字をつけて示すと，定常状態 に達した場合には

$$
\begin{aligned}
& F=P, \quad D=E \\
& D=P+T, \quad E=F+T \\
& D \cdot S_{D}=P \cdot S_{P}+T \cdot S_{T} \\
& E \cdot S_{E}=F \cdot S_{F}+T \cdot S_{T}
\end{aligned}
$$

(1). (2)，(3) および (3') 式より

$$
\begin{aligned}
& s_{D}=\left(\frac{1}{1+C l}\right) s_{P}+\left(\frac{C l}{1+C l}\right) s_{T} \\
& s_{E}=\left(\frac{1}{1+C l}\right) s_{F}+\left(\frac{C l}{1+C l}\right) s_{T}
\end{aligned}
$$

ただし

$$
\begin{aligned}
C l & =T / F=\left(S_{P}-S_{D}\right) /\left(S_{D}-S_{T}\right) \\
& =\left(S_{F}-S_{E}\right) /\left(S_{E}-S_{T}\right)
\end{aligned}
$$

と定義され，循環比 (Circulating Load) とよばれる重 要な变数である。

\section{§3. 粉末の粒度分布と比表面楀の関係}

一般飞粉末の比表面積 $S\left[\mathrm{~cm}^{2} / \mathrm{cm}^{3}\right]$ と粒度分布累積 函数 $R$ との間にはつきの関係がある。

$$
S=-\phi \int_{x_{2}}^{x_{1}} \frac{1}{x} \cdot\left(\frac{d R}{d x}\right) d x
$$

ここに $x$ は粒径で添字 1，2 はそれぞれ粒子り上限と下 限を示し， фは形状係数である。

水平回転ミルを用いた場合，砕製物の粒度分布には

$$
R=e^{-k x^{n}}
$$

が成立ち"，(6) 式は解析的に糟分が可能である。この 際工学的に $n^{\prime}$ は1飞近い值といわれるので $n^{\prime}=1$ と仮 定する。また粒子の上限と下限の值をいかにとるか楉 干問題はあるが、ひとまず $x_{2} ， x_{1}$ はそれそれれ $R_{2}=99.9$ $\%, R_{1}=0.1 \%$ に対応する值を入れ，後に検討と補正を 加える。よって

$$
x_{1}=\log 1000 / k \cdot \log e
$$




$$
x_{2}=0.00043 / k \cdot \log e
$$

また形状係数 фはすへての場合に 6 と仮定する。

つぎ碎製物をセパレータで分粒し，篩上（戻粉）と 篩下（精粉）にわ愓合，一定の限界径 $x_{0}$ で完全に分 割されるるのと仮定する。すると節下 $P$, 䈔上 $T$ の残 㳯 $R_{P} ， R_{T}$ はそれぞれ

$$
\begin{aligned}
& R_{p}=\left(e^{-k x}-e^{-k x_{0}}\right) /\left(1-e^{-k x_{0}}\right) ; x<x_{i} \\
& R_{T}=e^{-k x} / e^{-k x_{0}} \quad ; x>x_{0}
\end{aligned}
$$

これより

$$
\begin{aligned}
& S_{P}=-6 \int_{x_{2}}^{x_{c}} \frac{1}{x} \cdot \frac{d}{d x}\left(\frac{e^{-k x}-e^{-k x_{e}}}{1-e^{-k x_{0}}}\right) d x \\
& S_{T}=-6 \int_{x_{c}}^{x_{1}} \frac{1}{x} \cdot \frac{d}{d x}\left(\frac{e^{-k x}}{e^{-k x_{0}}}\right) d x
\end{aligned}
$$

しかるに

$$
\frac{d R_{p}}{d x}=\frac{-k e^{-k x}}{1-e^{-k x_{c}}}=\frac{-k}{1-e^{-k x_{c}}}\left(1-k x+\frac{(k x)^{2}}{2 !}-\cdots\right)
$$$$
\therefore S_{P}=\frac{6 k}{1-e^{-k x_{0}}} \cdot\left(\ln \frac{x_{0}}{x_{2}}-\right.
$$

（9）式を用いて

$$
\begin{aligned}
& S_{P}=\frac{6 k}{1-e^{-k x_{c}}} \cdot\left(\ln \frac{k \cdot x_{c} \log e}{0.00043}-\right. \\
& \left.\sum_{n=1}^{\infty}(-1)^{n-1} \cdot \frac{k^{n}\left\{x_{c}{ }^{n}-(0.00043 / k \log e)^{n}\right\}}{n \cdot n !}\right)
\end{aligned}
$$

同様に

$$
\begin{aligned}
& S_{T}=\frac{6 k}{e^{-k x_{0}}}\left(\ln \frac{3}{k x_{c} \log e}-\right. \\
& \left.\sum_{n=1}^{\infty}(-1)^{n-1} \frac{\left.k^{n}\left\{(3 / k \log e)^{n}\right)-x_{c}{ }^{n}\right\}}{n \cdot n !}\right)
\end{aligned}
$$

また

$$
\begin{aligned}
& S_{D}=6 k\left(\ln \frac{3}{0.00043}-\right. \\
& \left.\sum_{n=1}^{\infty}(-1)^{n-1} \frac{\left\{(\ln 1000)^{n}-(0.00043 \times 2.3)^{n}\right\}}{n \cdot n !}\right) \\
& \infty k
\end{aligned}
$$

\section{\$4. 諸変数の関係を示す共線図表}

(13)，(13')および（14）の各式を（4）式に代入すれ ば, 閉回路粉碎に括ける分離限界径 $x_{0}$, 粒度分布常数 $k$ および循環比 $C l$ との関係が与えられる。

$$
\begin{aligned}
& \text { 一方 } \\
& \quad C l=T / P=R c /(1-R c)=e^{-k x_{c}} /\left(1-e^{-k x_{\varepsilon}}\right) \\
& \text { より } \quad R c=e^{-k x_{e}}=C l /(1+C l) \\
& \therefore \quad k x_{e} \log e=\log (1+1 / C l)
\end{aligned}
$$

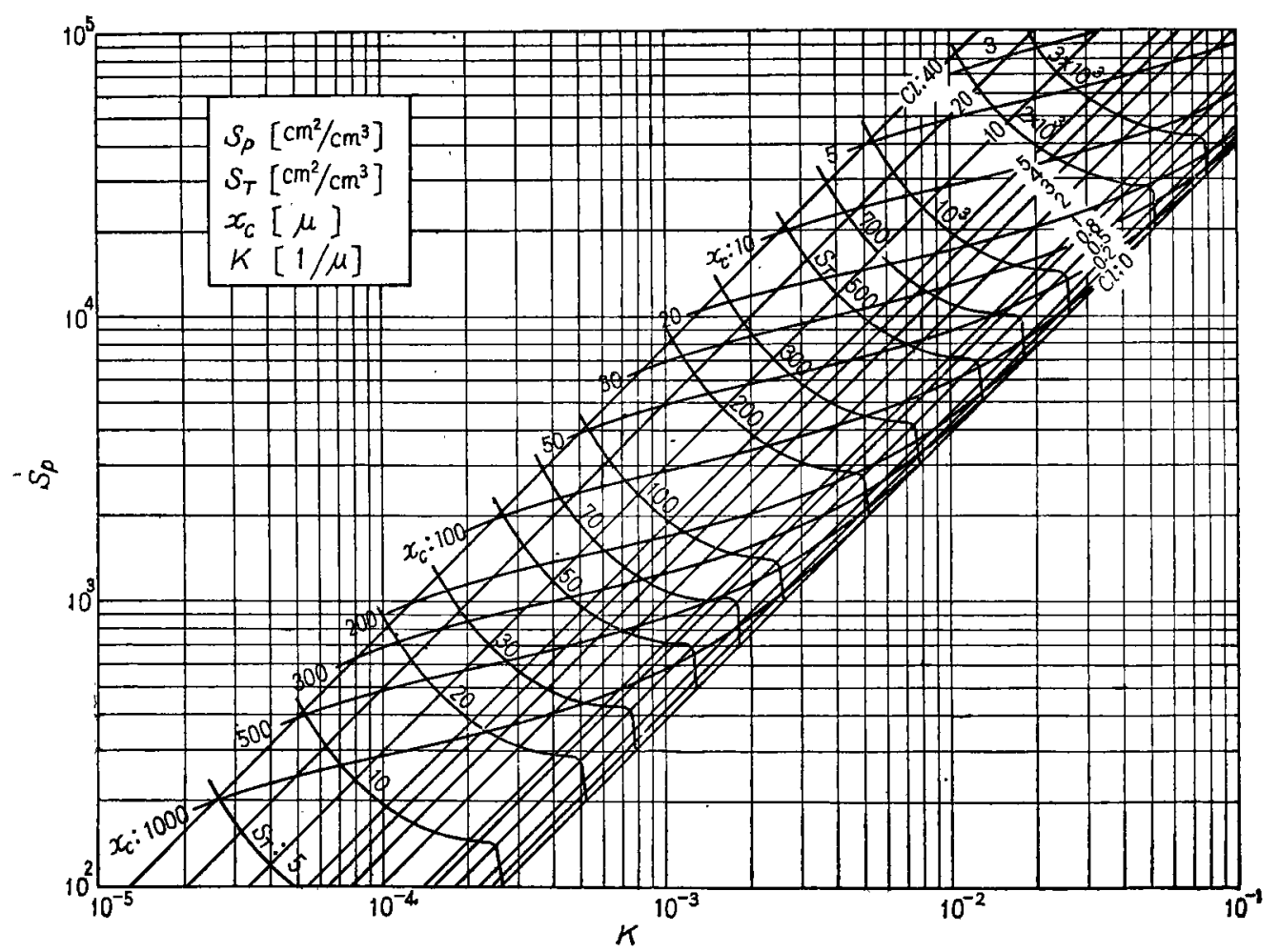

Fig. 2 Chart of clased circuit grinding operation (No. 1) 
（12）（13）および（16）式より Clの一定值代対しすべ $\tau$

$$
S_{P} \infty k
$$

ゆ光に各 $\mathrm{Cl}$ の一定值に対し， $S_{P}$ を両対数虾にとると $45^{\circ}$ の公配をるつ平行直線群を得る。また (13) 式より $x_{0}$ 一定の場合の $S_{P}$ を求め, Fig. 2 のことき各曲線群を 得た。

つぎ同一の $k$ 幽よび $C l$ の值に対して $\left(13^{\prime}\right)$ 式より $S_{T}$ の值がわかるから，Fig. 2 の上K $S_{T}$ 一定の各点を読 んで四に示すような曲線群を描くことができる。さらに メ。と $k$ とを一層細かく読むために，座標軸を変えた図を Fig. 3 K示す。曲線群は $S_{P}$ の一定値に対応するるので ある。

困の使用法として，たとえば $k=0.01(1 / \mu)$ で比表面 稍 $10^{4}\left[\mathrm{~cm}^{2} / \mathrm{cm}^{3}\right]$ の昐末を得たい場合, Fig. 2 または 3 を用いて，両方の坐標より点をきめるとそのときのセバ $\nu$ タの分離径 $x_{0}=41 \mu$, 循環比は 2.0 , 循愣物の比表

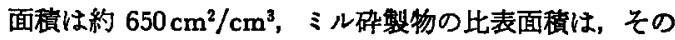
点から垂線を下し, $C l=0$ の直繶 との交点の絽座標より ' $S_{D}=3800 \mathrm{~cm}^{2} / \mathrm{cm}^{3}$ となる。る る碎料の比表面積がわか れば，ミル入口の粒子の比表面積 $S_{E}$ は (4') 式を用いて 副算することができる。

\section{5. 图表作㱔に用いた仮定に関する検討} 前節のチャートを作る際の仮定はつぎのように要約さ れる。

1)（6）式で $\phi=6$ とおいたこと。2）指数法則が成立 しかつ $n^{\prime}=1$ とおいたこと。3）上限と下限とにそれそ れ $R=0.1 \% ， 99.9 \%$ に対応する值をとったこと（式 (8)， (9))。4）分離限界径で完全に粒子が 2 つに分剨され, 効率 100\%と考えたこと，などである。

以上に関する吟味として

1)は一般俅以外のるのでは ф>6 となるが, 特定の 粒子径（たとえば Guttman 径）を用いた場合 $\phi \doteqdot 6$ と なるといら報告》がある。るちろんめの值があらかじめ 既知の場合, チャートの上で適当俌正することるでき る。

2）この法則性は，水平回転ミルの場合にのみ比較的 よく満足されるのであるが，こく特殊の粉哗機を除いて 衝撃，圧縮力によるものではある程度適用されるすのと 思われる22。また $n^{\prime}$ の値は主として物質によって变わる と考えられるが，実際に取扱5多くの物質（たとえば珪 砂，セメント，珪石質岩石）などでは概ね1に近い值で ある。また $n^{\prime}$ の值の多少の変化はチャートの上に大し た変化を与完ないと思5。

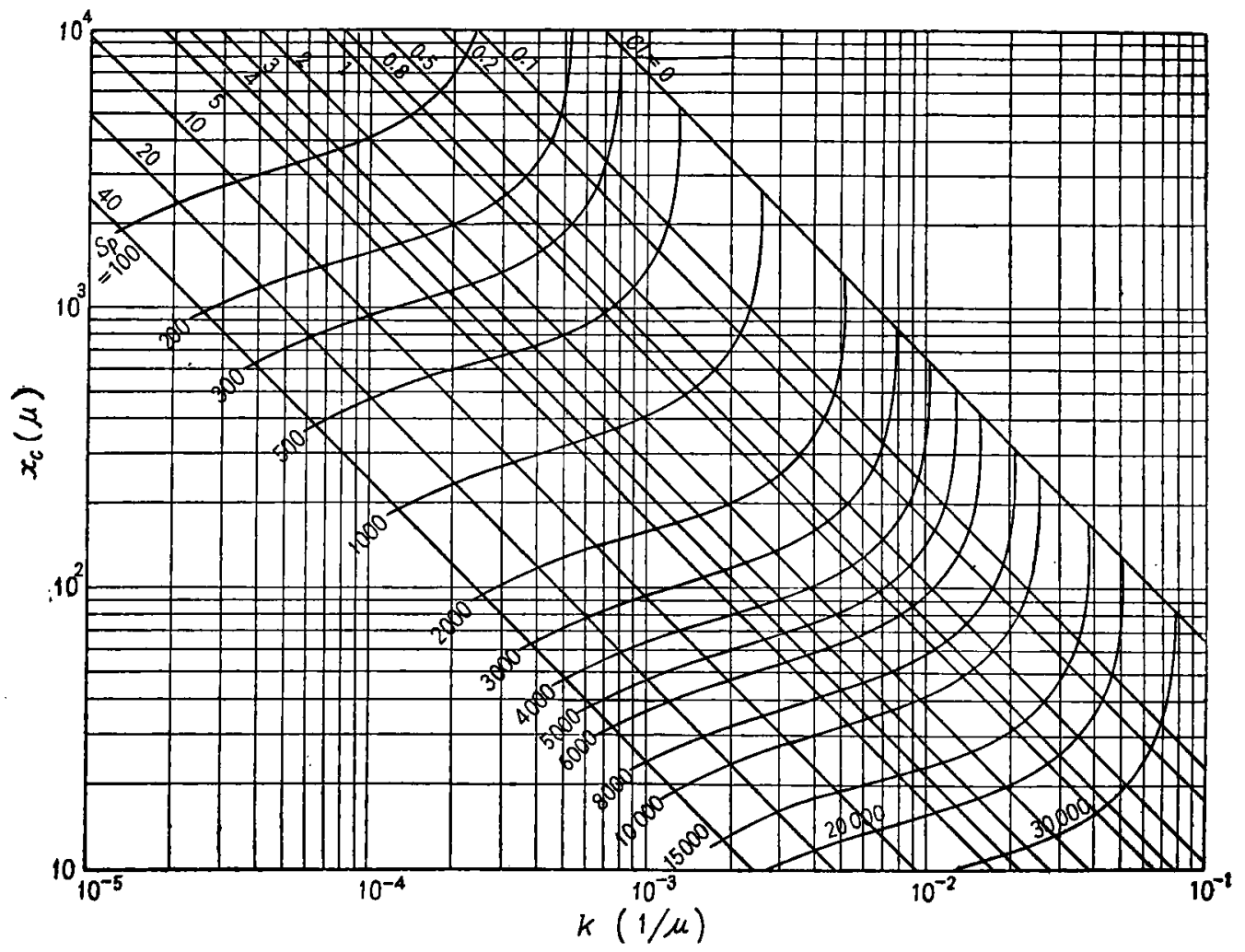

Fig. 3 Chart of closed circuit grinding operation (No. 2) 


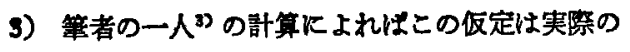

培合適当ではなく，たとえば広く工業的に用いられる Blaine法の比表面榼值との間にはかなり差がある。し かしこれは注とんと微粉側の限界值炕よるるのと思わ れるので, Fig. 4 に示す Blaine 值と（14）式による $S$ との関係から実際の埸合には補正を行兊ばよく, 他 には影慗はない。

4）この仮定は，選粉機の性能のよくないるのには 大体が無理な仮定であるから，今後の研究により改め ねばならね。しかしるし各セパレータの部分分粒効率 之粒径との関係が既知ならば，要求に応じて $x_{0}$ の位置 をずらせてやることがでぎ、ャートはとのまま使用 できることになる。

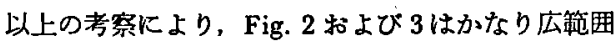
に, 所要の粉末を得るための閉回路粉碎操作条件の選 定や設計に役立つるのと思われる。

\section{\$6. 各粉末の細かさと循環比との関係}

\section{1. 繁品の粒度分布}

（7）式が成立つ場合には両辺の対数を 2 度とって

$\log (-\log R)=\log k+\log \cdot \log e+\log x$ 両対数䋎に $x$ と $(-\log R)$ をとれば勾配 $45^{\circ}$ の直線を得る。同様に（10）式と (15') 式より

$$
\begin{aligned}
& \log R_{P} \\
& \quad=\log \left(e^{-k x}-e^{-k x_{e}}\right)-\log \left(1-e^{-k x_{c}}\right) \\
& \quad=\log \left\{e^{-k x}-C l /(1+C l)\right\}+\log (1+C l)
\end{aligned}
$$

となり，上と同じブロットの方法では一

般に直線にはならない。

一方 (12) 式よ゙り頻度曲線は

$$
-d R_{P} / d x=k e^{-k x} /\left(1-e^{-k x_{0}}\right)
$$

$\therefore \log \left(-d R_{P} / d x\right)=\log k$

$$
+\log (1+C l)-k x \log e
$$

由えに片対数拜に $-d R_{P} / d x(>0)$ と 点緅すれば, 勾配は $k \log e$, 截片は $k(1+$ Cl）の読みを与える。

\section{（A）比表面積 $S_{P}$ を一定にして粒度分} 布を変えたい場合 Fig. 3 より $S_{P}$ 一定 の值に怙いてて任意の $\mathrm{Cl}$ K対応する $k$ を求め（18）式に したがって すると Fig. 5 を得る。 $\mathrm{Cl}$ の增大ととるに各粒径の覑度 は揃い，かつ粒径の範围は狭まる。ただし実際にはある 一定の粒径上り細かいところでは，粒度分布は (7) 式を 满足せず $-(d R / d x)$ は急減少するはずであるから， $x$ のある值で最大値が現われる。いま仮に $n^{\prime}=1.03$ と考

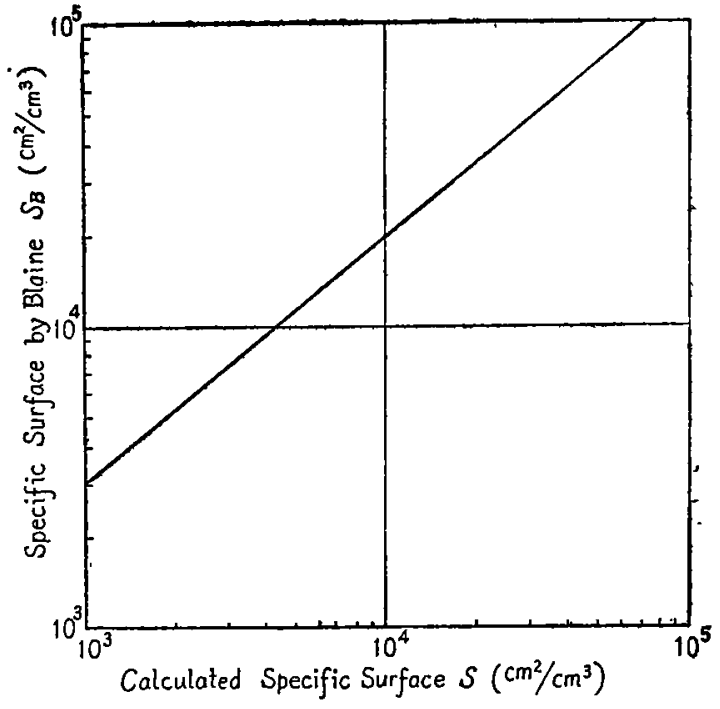

Fig. 4 Correlation of the specific surface obtained by Blaine method with those obtained by calculation

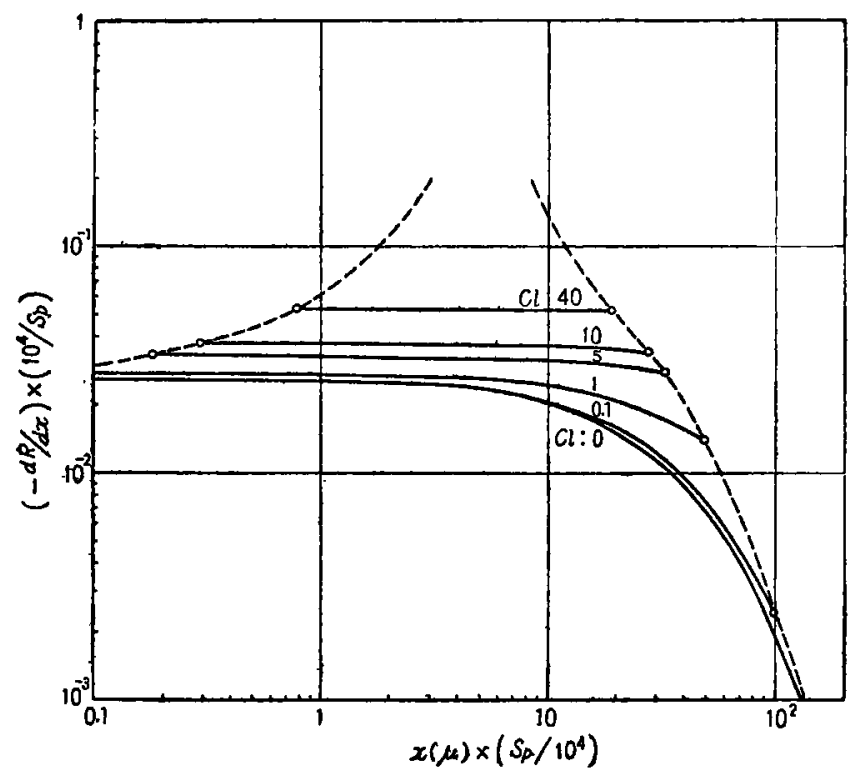

Fig. 5 Frequency of finished product vs. particle size at the constant specific surface of product

えて $-\left(d R_{P} / d x\right)$ の最大值を与える $x_{\boldsymbol{n}}$ を求めてみると

$$
\begin{aligned}
-d R_{P} / d x & =k n^{\prime} x^{n^{\prime}-1} e^{-k z^{n^{\prime}}} /\left(1-e^{-k x_{e^{\prime}}{ }^{\prime}}\right) \\
& =k n^{\prime} x^{n^{\prime}-1} e^{-k x^{n^{\prime}}}(1+C l)
\end{aligned}
$$

$\therefore \quad-d^{2} R_{P} / d x^{2}=k n^{\prime}(1+C l) x^{n^{\prime}-2} e^{-k n^{\prime}}$

$$
\left\{\left(n^{\prime}-1\right)-k n^{\prime} x^{\prime \prime}\right\} \equiv 0
$$

と拉いて

$$
x_{m}=\left\{\left(n^{\prime}-1\right) / k n^{\prime}\right\}^{1 / n}
$$




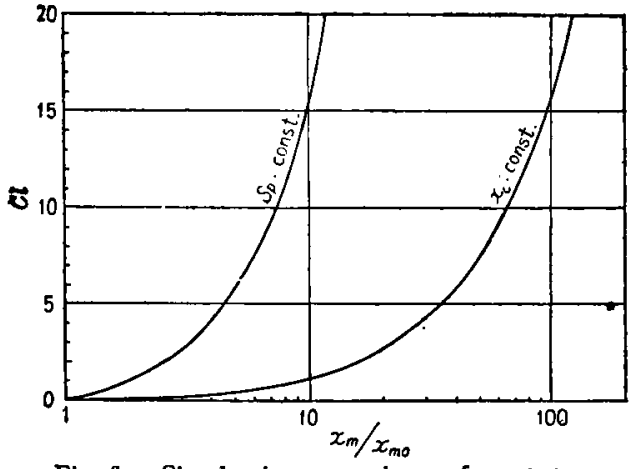

Fig. 6 Size having a maximum frequency against the corresponding circulating load

$$
x(\mu) \times\left(S_{p} / 10^{4}\right)
$$

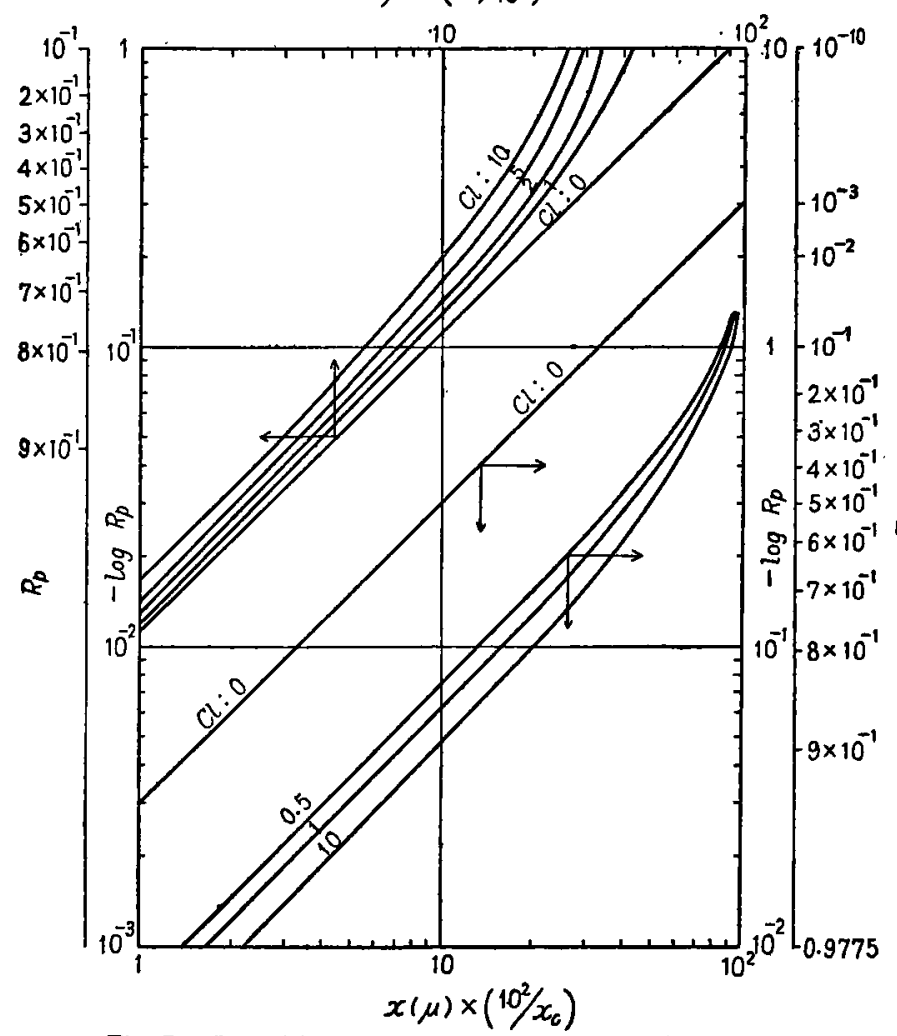

Fig. 7 Logarithmic plot of size distribution of product vs. particle size る。 揃 5 傾向をつ。

方法にならって両対数上に示すと Fis. 7 の上部に示 す曲線群となる。よって所要の $R_{P}$ の值と $x$ により, 必 要な $k$ の值また㑑環比を推定することができる。なお 両座標軸は任意の $S_{P}$ (または後述の $x_{\theta}$ ) より直ちにそ の場合の $R_{P}$ と $x$ とがわかるように補正值を採用してあ

（B） 分離限界径 $\boldsymbol{x}_{c}$ を一定にしたい場合 前項と 同様に $S_{P}$ の代りに $x_{c}$ を一定として Fig. 2 または Fig. 3 上り $C l$ に対応する $k$ をよみ，同じ計算を施した結果 を Fig. 8 および Fig. 6，7の $x_{c}$ : const. の各曲線に示 した。この場合一般に粉末は粗くなるから，前項の場合 と反対に分布曲線は下方にずれてくる。粓径はるちろん

\section{2. 製品の比表面䅡および 粉砕能力}

開回路粉硑の場合の, 粉碎容量を $F_{0}$ とし，そのときの製品の比表面 積を $S_{P 0}$ とすれい゙，粉碎機によって 新しく生成する総表面積の增加は, Rittinger の法則があてはまるるの と仮定して

$$
F_{0}\left(S_{P 0}-S_{F}\right)=K \cdot W
$$

ただし $W$ は粉碎所要動力, $K$ は恒数 とする。

同一のミルを同一条件で運転する 場合, 任意の $\mathrm{Cl}$ において，すし $K$ 分粉碎条件比よって变らぬすの仮 定士れば (4)，(4') 式より

$$
\begin{aligned}
E\left(S_{D}-S_{E}\right) & =F(1+C l)\left(S_{D}-S_{E}\right) \\
& =F\left(S_{P}-S_{F}\right) \\
& =K \cdot W
\end{aligned}
$$

(21)，(22) 式より

$$
F / F_{0}=\left(S_{P_{0}}-S_{F}\right) /\left(S_{P}-S_{F}\right)
$$

$S_{\text {F が }} S_{\boldsymbol{P}}$ に比較して無視される場 合には

$$
F / F_{0}=S_{P_{0}} / S_{P}
$$

(A) $\boldsymbol{S}_{P}$ 一定の軥合 このと きはもちろん粉碎能力は $C l$ をか克 てあ原則的には变化がない。

前の $k$ をとのま用いて $x_{m}$ を計算し，対応する $\mathrm{Cl}$ と を点綴すると Fig. 6 の $S_{P}$ : const. の曲線を得る。るっ とす $\mathrm{Cl}$ の值によって $n^{\prime}$ の值に一定の変化の傾向があら われる可能性もあるが，これは実測值にまたねばならな い。

また残涬函数 $R_{P}$ と $x$ との関係は，従来行われている
(B) $x_{0}$ 一定の場合 前項々同様に $x_{0}$ 一定におけ

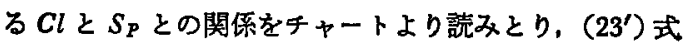
によって $F / F_{0}$ を計算すれば Fig. 9 のことき $C l$ との関 保が得られる。すなわち $\mathrm{Cl}$ Kよって著しく粉砵能力は 增加する。実際にはこの 1/3 位つになるが，これは(21) 式の $K$ がミル内通過速度の函数であると考えられ、いま 
一つ大きい問題は，一般にミルの出入口にお ける粉末度の差が大きい場合には Bond の法 則がよりよく適用されるはずで，(23') 式の 右辺は近似的飞 $\sqrt{\overline{S_{P 0} / S_{P}}}$ に等しくなり，乙 たがって Fig. 9 からかかるように大体理論 と実際の值とが一致してくる。

3. その他の粉体の比表面積

粉啸機の操作や設計のためにはミルの入口 出口の粉末度すなわら $S_{E} ， S_{D}$ を知らねばな らぬ。また $x_{0}$ 注セレクターの操作条件, 循 罡物の細かさ $S_{T}$ は粉体輸送装置の設計汇役 立つ。これらの值と循環比の関係をつぎに述 ベる。

(A) $S_{P}$ 一定の場合 Fig. 2 または 3 より $S_{P}$ 一定に対する $\mathrm{Cl}$ k対応する $S_{D}$ を求 めると Fig. 10 の $S_{D}$ 曲線のよ 万に $\mathrm{Cl}$ の増 加ととるに減少する。

同様に $S_{T}$ を追跡すると， $\mathrm{Cl}=0.1$ まではほとんど一 定值 $\left(S_{P}\right.$ の約 1/10) であるが，それより $\mathrm{Cl}$ が大きくな るとやや複雑な曲線を画いて減少する。いうまでるなく この場合の最小粒径は $x_{\varepsilon}$ であり，この $x_{c}$ と $C l$ との関 係を Fig. 11 亿示す。

つきに $\left(4^{\prime}\right)$ 式によって前述の $C l$ と $S_{T}$ との関係を用 いて $S_{E}$ を求めることができる。 $S_{F}$ を無視小と仮定する そ

$$
S_{E}=\{C l /(1+C l)\} S_{T}
$$

Fig. 10 の $S_{F}$ 曲線のよ $5 飞 ~ C l=3.0$ 付近に極大值があらわれる。これはミ ル入口の粉末が一番紐かくなるところ で, 粉碎機の操作にとっては大变有利 な条件を与える。たと兊ば粉碎媒体の 大きさの調整が容易となって，粉砕機 の合理的操作にとって一つの大きいめ やすとなると考元れる。

（B） $\boldsymbol{x}_{c}$ 一定の場合 同様の方法 で $S_{D}, S_{T}$ および $S_{\Xi} を C l$ の值に対 して追跡すると Fig. 12 の各曲楾を得 る。この場合前項の各値の変化よりも やや急であり, また $S_{E}$ の極大值は $C l$

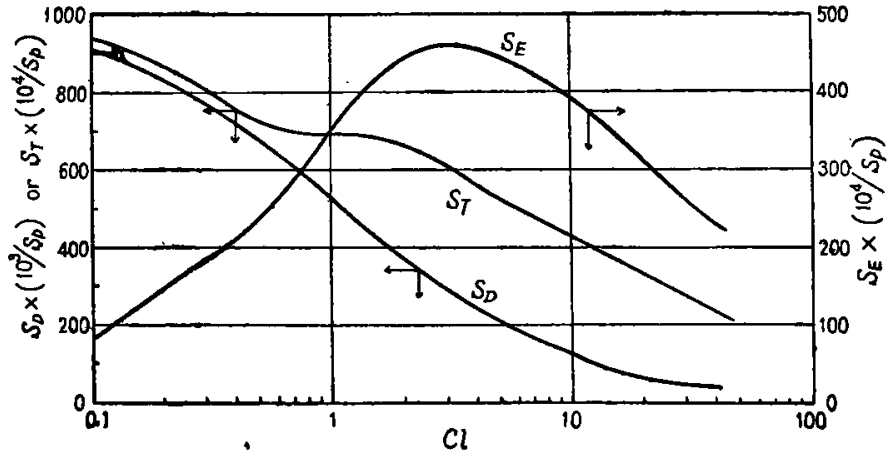

Fig. 10 Specific surface of some variables against the circulating load at the constant specific surface of product

えたい場合には，一般に閉回路粉碎方式によらねばなら ない。この場合の粉砕機，分粒機，粉体輸送装置の設計， 型式選定または操作条件の選定绻当って必要な種々の粉 末の細かさ，たとえばミルの入口，出口，分粒機よりの 㞍り粉，さらに分粒限界径や容量を決定する㡒㻴比との 相互関係を，2，3 の仮定に基ついて Fig. 2 おび 3 の 


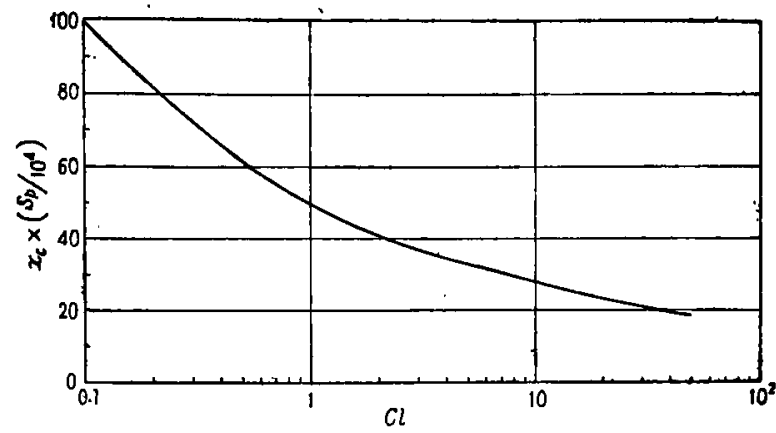

Fig. 11 Cut off size vs. circulating load at the constant $S_{P}$

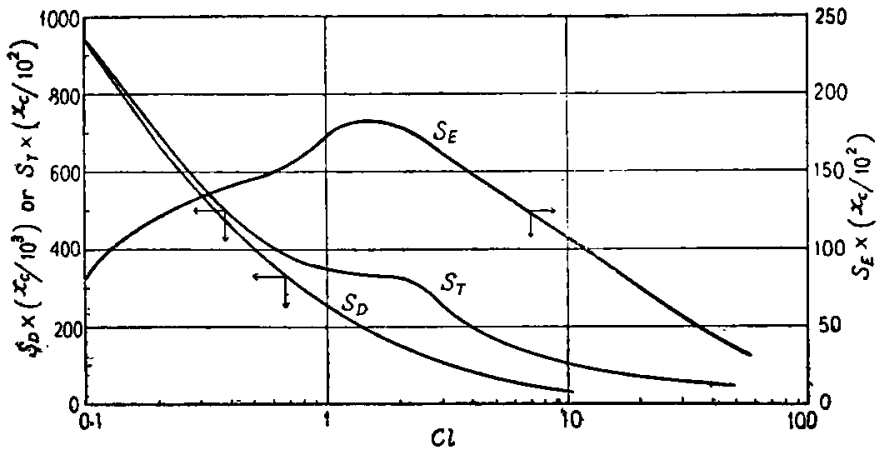

Fig. 12 Specific surface of some variables against the circulating load at constant cut off size
に変るかをチャートを用いて追跡しだ。 なお実際の操作ではミル内をエアースェブ トにする方法を組合せ，微粉ととるに発生熱 の除去による効率の向上を計ることがある。 これらの機俩により粉末の細かさの調整は, 一圈複雑な因子に支配されると想像されるが 本報に述へた結果は十分一つの基本的なるの を与えていると思5。

\section{Nomenclature}

$$
\begin{aligned}
& C l: \text { Circulating Load } \\
& D: \text { Rate of Mill Discharge }
\end{aligned}
$$

[ton $/ \mathrm{hr}$ ]

$E$ : Rate of Mill Charge [ " ]

$F:$ Rate of Feed [ " ]

$P$ : Rate of finished Product [ " ]

$T:$ Rate of Recycle [ "]

$R$ : Residue [-]

$S:$ Specific Surface $\left[\mathrm{cm}^{2} / \mathrm{cm}^{3}\right]$

$x$ : Particle size [ $[\mu]$

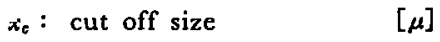

$k(1 / \mu), n^{\prime}:$ constants of Rosin-Rammler Eq.

$\phi$ : Shape factor

[一]
チャートに示し, 所要の条件より直らにすべての変数の

值をよみとれるよ5にした。

ついで実際に行われる製品の比表面稍るしくは許容最 大径のいずれかを一定にして，製品の性質を任意に变化 させたい場合について，製品の粒度分布や上述の諸粉末 の細かさささらにミルの粉砕能力が循環比によっていか

\section{Literature Cited}

1) K. Chujo: Kagakukogaku to Kagakukikai, 7, 1 (1949)

2) Nakagawa et al: Chem. Eng. (Japan), 19, 349 (1955)

3) T. Tanaka : Chem. Eng. (Japan), 19, 152 (1955)

4) Brown: "Unit Operation" p. 41 (1950) J. Wiley

\title{
Fineness Control of Product by Closed-Circuit Grinding
}

\author{
T. Tanaka, M. Ojima, ${ }^{*}$ K. Kuwano*
}

Specific surface of finished product and its size-distribution may be independently controlled by closed-circuit grinding. However, there has hardly been established any standard for the techniques: how to design, select and operate a mill and classifier, how to determine the capacity of powder transportation equipments, etc.

Based on the Rosin-Rammler exponential law, the authors drew up the "Charts" (Figs. 2 and 3), by which one can easily obtain the values of several variables such as fineness of mill discharge, amount of product and recycle from the classifier in correlation to the circulating load, cut-off size of a classifier and constants of size-distribution.

The authors pursued, on the basis of these charts, general changes of size-distribution of the 
product, and of the specific surface of various powders in accordance with the increment of the circulating load, and found that when $C l=1.5$ or 3 , there existed finest value, hence may be optimum, of the composite feed to a mill, which value was dependent upon the required property of the finished product.

By comparing the specifice surface of the product obtained by closed-circuit grinding with that obtained by open-circuit grinding, the authors found that the theoretical increase of the capacity of grinding mill was somewhat greater than the practical one, provided the constant of Rittinger's law remained, unchanged regardless of the speed-up of powder movement through the mill.

- Faculty of Engineering, Kanazawa University

余白を利用させていたたいいて，例題を解いてみ ๖。

[例遉]チューブミルでセメント原料（比重 2.7)を毎時 15 ton の割合で開回路粉碎を行い，碎 製物の料度分析の結果下表のことき数值を得た。 $\begin{array}{lrrrrr}\text { 徨 } x(\mu) & 5.2 & 9.2 & 16.1 & 29.8 & 52.1 \\ \text { 箖上 } R(\%) & 84.8 & 75.8 & 61.1 & 40.0 & 17.2\end{array}$

碀製物の性質を変えるために上と同一の比表面

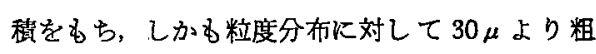
い粒子を除去した粉末を得るため，このミルを閉 回路にして分級機を借える場合，分級機の処理量 と入汾の細かさおよび戻粉の輸送機の処理量と 粉末の比表面積を求む。また製品の粒度分布はい

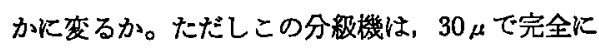
粗粒と微粉とに分制できるるのとして計算せよ。

[解]ます開回路粉碎の粉度分析結果上り，

$(2-\log R)$ と $x$ とを雨刘数㼏上にプロットする 々直線を得，それから実酫式を次のように得る。

$$
R=100 e^{-0.029 x^{1.02}}
$$

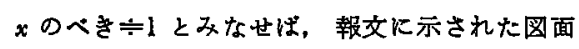

Fig.2を使用できる。すなわちこの粉末の比表面 穔林横軸 $k=0.029(1 / \mu)$ と $C l=0$ の直線との 交点の綪座標で与えられる。題意により，閶回路 にした場合、これと同一の比表面穞の製品を得た いのだから，その交点より水平線を引いて，分離 径 $x_{0}=30 \mu$ を示す曲線との交点を求めると，その 点を通る循環比 $C l \fallingdotseq 5$, かつ横座標より $k=0.006$

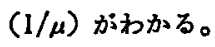

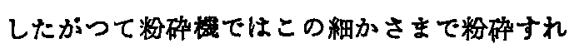

ばよいわけで，この比表面䅡 $\left(S_{D}\right)$ は上飞求め た交点より垂線を下し， $C l=0$ の直線との交点の 縦來標をみればよい。これが分級機に送り込まれ る入粉の細かさになる。

$$
\therefore S_{D}=2350\left(\mathrm{~cm}^{2} / \mathrm{cm}^{3}\right)=870\left(\mathrm{~cm}^{2} / \mathrm{g}\right)
$$

また上述の交点を通る㞍粉の細かさ $S_{T}$ の曲線 より

$$
S_{T} \fallingdotseq 600\left(\mathrm{~cm}^{2} / \mathrm{cm}^{3}\right)=220\left(\mathrm{~cm}^{2} / \mathrm{g}\right) .
$$

製品の量 $(P)$ 每時 15 ton を得るむのとすれは， 循環比 $C l=T / P=5$ 上り

$$
\begin{aligned}
& \text { 戻粉の量 }=5 \times 15=75 \mathrm{ton} / \mathrm{hr} \\
& \text { 分級機入羒 }=75+15=90 \mathrm{ton} / \mathrm{hr}
\end{aligned}
$$

以上で所要の分級機と榆送機の設計資料が得られ たわけである。

つぎに製品の粒度分布は一般に次式のようにな る。

$$
R_{P}=\frac{e^{-k x}-e^{-k x_{0}}}{1-e^{-k x_{0}}} \times 100(\%)
$$

これに $k=0.006(1 / \mu) x_{0}=30 \mu$ を入れれは

$$
R_{P}=606\left(e^{-0.006 x}-0.835\right)
$$

因みに問題に与元られた表と同じ粒径 $x$ に対する $R_{P}$ を計算すると

$$
\begin{aligned}
& \begin{array}{lrrrrr}
\text { 粗茥 } x(\mu) & 5.2 & 9.2 & 16.1 & 29.8 & 52.1
\end{array} \\
& \begin{array}{llllll}
\text { 睟上 } R_{P}(\text { \%6) } & 81.7 & 66.7 & 43.7 & 0.6 & \text { - }
\end{array}
\end{aligned}
$$

比表面稓は同一でも粉度分布はよ注ど资化したこ とがわかる。ただし上はすへて分級機が理想的 飞働いた場合に限るすので，実際炕は限界徍附近 飞相互の混入があるため数值的にも相当異つた綃 果が出てくることに留意すべきであろう

[田 中] 